\title{
COST ESTIMATION PERFORMANCE IN THE CONSTRUCTION PROJECTS: A SYSTEMATIC REVIEW AND FUTURE DIRECTIONS
}

\author{
Mohammad Waffy Fazil ${ }^{1}{ }^{*}$, Chia Kuang Lee ${ }^{1}$ and Puteri Fadzline Muhamad Tamyez ${ }^{1}$ \\ ${ }^{1}$ Faculty of Industrial Management, Universiti Malaysia Pahang, Gambang, Malaysia
}

ABSTRACT - Cost estimation in a construction project is very critical to avoid cost overrun in the project. This paper aims to provide a basis to improve cost estimation performance in construction through a systematic review of previous studies for the last 31 years. The papers identified a total of 238 construction cost estimation papers in 23 journals. Only 33 papers focused on factors influencing the performance of cost estimation. These papers were then analyzed, synthesized, and summarized in terms of the distribution across countries and citation influences. The factors of cost estimation performance were clustered into several themes with most of the factors in control themes. The factors in control themes are cluttered based on Organizational Control Theory (OCT). However, control themes provide less conceptual basis and dynamic to explain cost estimation performance and relationship among the factors. Therefore, this study reclassified other factors of cost estimation performance with reference to Contingency Theory (CT) and TaskTechnology Fit Theory (TTFT). Hence, a new framework with a relationship among the factors and cost estimation performance was developed. Further development and research of using the CT and TTFT frameworks were also discussed.

\author{
ARTICLE HISTORY \\ Received: 1-3-2021 \\ Revised: 7-4-2021 \\ Accepted: $17-5-2021$
}

\section{KEYWORDS}

Systematic literature

review

Cost estimation

performance

Task-technology fit theory

Contingency theory

Organizational control

theory

\section{INTRODUCTION}

The growing importance of construction projects in recent years toward economic and social perspectives has significantly improved cost estimation progress. For several decades, many researchers have explored the knowledge area of project performance. Nevertheless, the construction projects still comprise a high risk to be unsuccessful. The project experience in time overrun is a frequent cause of difficulty in construction projects in developing countries (Aziz, 2013; Mahdi \& Soliman, 2021). Malaysia also experiences time overrun in construction projects, with $80 \%$ of the project have an unnecessary delay in completion (Shehu et al., 2014). Poor cost estimate performance has caused project failure (Project Management Institute, 2018). Therefore, cost estimation is one of the primary factors in avoiding project failures such as cost and schedule overruns in construction projects.

Furthermore, the problem of inaccurate cost estimation has rarely been explored and investigated by researchers. Thus, it is critical to conduct a systematic review of previously published articles regarding cost estimation in construction projects. It will help researchers to understand the status and research trends of the topic for future research and help practitioners achieve project success.

The majority of cost estimation research discussed various cost estimation methods such as fuzzy expert system, cost estimation under uncertainty, building information modelling (BIM) software programs, structural equation method (SEM), expert's judgment, Monte Carlo simulation, historical data, case-based reasoning (CBR), artificial neural networks (ANNs), parametric, and unit cost (Barakchi et al., 2017).

In recent years, there were probably only three articles reviewed systematically within the area of cost estimation in the construction industry published in academic journals (Barakchi et al., 2017; Membah \& Asa, 2015; Tayefeh Hashemi et al., 2020). However, these systematic reviews were conducted based on different research objectives. Membah \& Asa (2015) review emphasized factors that contribute to cost underestimation and risks in cost estimation. Barakchi et al. (2017) focused on cost estimation methods. The review from Hashemi et al. (2020) focused on the cost estimation method, especially in machine learning techniques. Most past researchers rarely investigated the research trend of cost estimation in construction projects, especially regarding cost estimation performance factors. Hence, this study is vital due to the low amount of existing research on this perspective.

This systematic review extended the literature search to other related journals and aimed to address the following questions:

1. How did the general research trends on factors that influence the cost estimation of construction projects? (Timespan Overall, Overall Journal Shares, Distribution Across Countries)

2. What were the factors that influenced cost estimation performances in construction projects? 
3. What are the future research directions on cost estimation and use based on the results obtained from research questions 1 and 2 above?

This paper's remaining parts begin with the "Research Methodology" section, which describes the systematic review methodology. In the "Result" section, the findings are included, and the importance of the results are critically discussed. Lastly, the "Conclusion and Recommendations" section describes the conclusion and provides recommendations for future research.

\section{RESEARCH METHODOLOGY}

Research questions 1 and 2 have been responded through systematic review processes including summarizing, synthesizing, and interpreting previous literature. The systematic review process is shown in Figure 1 by integrating the review processes proposed by Siddaway et al. (2019) and Lee et al. (2016).

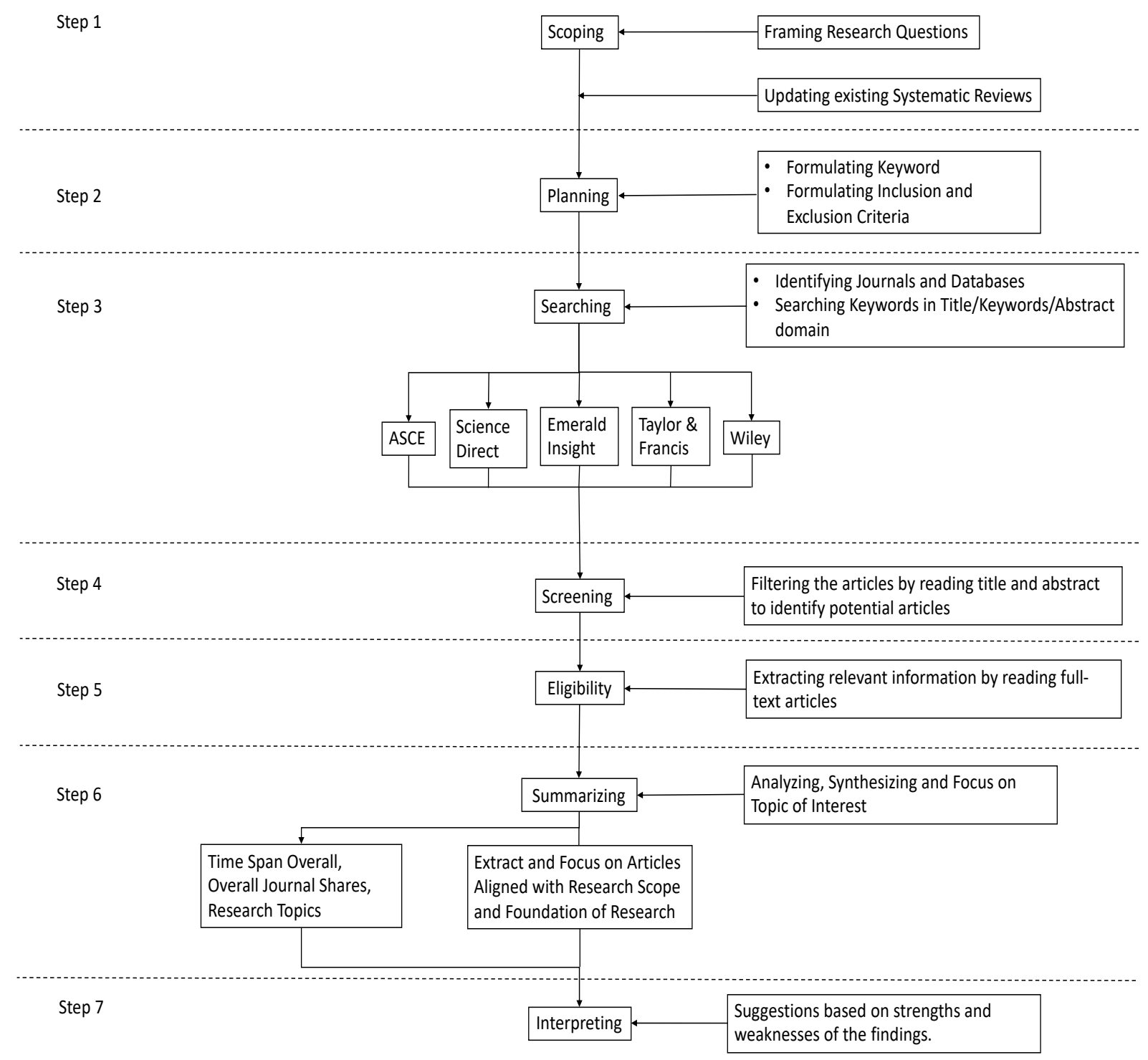

Figure 1. Steps of the systematic review

The systematic review was initiated by framing research questions and checking the previous reviews' similarity with the planned review in Step 1: Scoping (Siddaway et al., 2019). The research questions should have relationships or connections with the research topics to assist the researcher's tasks by making them more straightforward. Therefore, the tasks can be completed faster and easier (Siddaway et al., 2019). In Step 2: Planning, the individual concepts in the research questions were divided to create search terms purposely to identify the most potential papers. Moreover, different terminologies were included such as synonym and plural forms, to identify all relevant papers.

Additionally, preliminary inclusion and exclusion criteria were formulated and justified to find suitable papers easier (Siddaway et al., 2019). Next, appropriate databases and journals were identified to focus the search on the relevant domain in Step 3: Identification. The preliminary search was performed by using the predefined search terms into selected databases and journals with the findings focus on Title, Keywords, and Abstract. The utilisation of Boolean, wildcard and 
truncation symbol while performing the search tasks are advisable to reduce massive time consumption (Siddaway et al., 2019). Nevertheless, not all the search engine of databases has them. Furthermore, the search results were carefully inspected, and additional examinations were performed to ensure the results include important or critical studies. After that, the search results' references were exported to the citation manager and the title and abstract were read to determine whether the papers are related to the research questions in Step 4: Screening (Siddaway et al., 2019). Next, in Step 5 Eligibility, the relevant information from the eligible papers was extracted into tabulation form. It is essential to extract information from the full-text version, which relates to the research questions (Siddaway et al., 2019). In Step 6: Summarizing, the information of the eligible papers were synthesized and summarized according to the characteristic, quality and effect of the papers (Lee et al., 2016). As for the final step, Step 7: Interpreting, the obtained results were interpreted to develop the recommendation from the evidence of the potency and limitation (Lee et al., 2016).

Research question 3 has been responded by synthesizing the factors influencing the accuracy and performance of cost estimation in construction projects and interpreting the topic's research trend. The systematic review's weaknesses and limitations provide the future research direction and research gap of the topic.

\section{RESULT}

\section{Scoping}

In scoping stage, various vital issues must be well-thought-out. The review's research questions were developed according to the research topic and researcher interests purposely for a clear and comprehensive review (Siddaway et al., 2019). The research or framing questions for this paper are stated below:

1. How did the general research trends on cost estimation of construction projects? (Timespan Overall, Overall Journal Shares, Research Topics)

2. What were the factors that influenced cost estimation performances in construction projects?

3. What are future research directions on cost estimation and use based on the results obtained from research questions 1 and 2 above?

Moreover, other systematic reviews were searched to clarify the similarity of the review. From the search, Barakchi et al. (2017), Hashemi et al. (2020) and Membah \& Asa (2015) published systematic reviews in construction projects. However, this systematic review differs from preview reviews (Barakchi et al., 2017; Membah \& Asa, 2015; Tayefeh Hashemi et al., 2020) because this review has different objectives and using different databases. While all the reviews have an objective to support and improve cost estimation research, each review explored different approaches. Membah \& Asa (2015) focused on factors contributing to cost underestimation and risks in cost estimation. At the same time, Barakchi et al. (2017) and Hashemi et al. (2020) emphasized cost estimation methods. The main objective of this review is to determine the factor of cost estimation accuracy and performance. Membah and Asa (2015) used the Society of Civil Engineers (ASCE), Web of Science (WOS), Science Direct (SD), the Association for Advancement of Cost Engineering (AACE) International, and the Royal Institution of Chartered Surveyors (RICS). Additional databases were the Transportation Research Board (TRB) and Google as searching databases. Meanwhile, Barakchi et al. (2017) used Scopus and Web of Sciences, and Hashemi et al. (2020) utilized Science Direct (SD) and Google Scholar. However, this review performed the search process through Taylor Francis Group, Emerald Insight, Science Direct (SD), Wiley Online Publisher, as well as professional institutions such as the American Society of Civil Engineers (ASCE), the International Project Management Association (IPMA), and Project Management Institute (PMI).

\section{Planning}

The planning stage is essential to ensure that all related articles were identified. Based on the research questions "What are the factors that affect the accuracy of cost estimation in construction projects?" the search terms were obtained, and more search terms were developed to ensure all relevant studies were included in the review. The keywords used in the preliminary search were shown as below:

“Cost Estimate”, “Cost Estimates”, “Cost Estimated”, “Cost Estimation”, “Cost Estimating”, “Cost Forecast”, Cost Forecasts", Cost Forecasted", "Cost Forecasting", "Cost Predict", "Cost Predicts", "Cost Predicted", "Cost Predicting", "Cost Escalate", "Cost Escalation”, "Cost Escalating”, “Cost Underestimate", "Cost Overestimate", and "Cost Overrun”.

As the review focuses on the construction projects, the journals and databases' selection emphasize building, built environment, project management, and construction according to each database.

\section{Searching}

The extensive and comprehensive literature searching was performed in a searching stage. The systematic review was performed by searching multiple databases such as Science Direct (SD), Taylor Francis Group, Emerald Insight, Wiley Online Publisher, including professional institutions such as American Society of Civil Engineers (ASCE), International Project Management Association (IPMA), and Project Management Institute (PMI). The preliminary search was performed using keywords in the Planning stages within the domain of Title or Keywords or Abstract with no restriction enforced in the date range. A total of 3176 articles were identified after the preliminary search. 
The Science Direct database was reviewed, and two journals were selected, specifically Automation of Construction and International Journal of Project Management. In Wiley Online Publisher, only Project Management Journal was selected.

Furthermore, the subject of 'Building and Construction' was selected during the process of reviewing Emerald Insight. The selection of the subject is essential to include the papers in construction projects. The journals selected were Built Environment Project and Asset Management, Construction Innovation, Engineering, Construction and Architectural Management, Journal of Engineering, Design and Technology, and Journal of Financial Management of Property and Construction.

For the Taylor Francis Group, several journals were selected under the 'Build Environment' subject area to identify the potential papers. The journals in this database, namely as Transportation Planning and Technology, Transport Reviews, Structure and Infrastructure Engineering, Journal of the American Planning Association, Journal of Civil Engineering and Management, International Journal of Construction Management, International Journal of Construction Education and Research, International Journal of Management Science and Engineering Management, Construction Management and Economics, Building Research \& Information, and Architectural Science Review.

Under the American Society of Civil Engineering (ASCE), the journal selected were Journal of Management in Engineering, Journal of Infrastructure Systems, Journal of Construction Engineering and Management, and Journal of Computing in Civil Engineering.

As a result, the number of journals involved in this systematic review was 23 . From the selected journals, Construction Management and Economics, Journal of Construction Engineering and Management, Construction and Architectural Management, Journal of Management in Engineering, Engineering, International Journal of Project Management, Automation of Construction and Building Research \& Information were within the top 10 in the ranking of construction management journals (Wing, 1997). The selection of these journals improved the quality and impact of the result in this review paper.

\section{Screening}

In the screening stage, the search results from the previous stage have been assessed for prospective papers. This process requires visual examination of all 2344 articles to filter out non-scholarly papers such as "introduction", "editorial", "book review", "discussions and closures", "letter to the editorial", "article in press", and "announcement". Accordingly, articles that were under these broad categories were filtered and excluded from detailed analysis. However, articles such as "Forum", "Case studies", "Features", and "Scholarly Paper" were maintained. Moreover, the title or abstract of the papers were read to identify articles that have potential. In the screening process, 238 articles were identified to have potential from 23 journals related to cost estimation in the construction industry as shown in Error! Reference source not found. 
Table 1. Total articles after searching and screening processes.

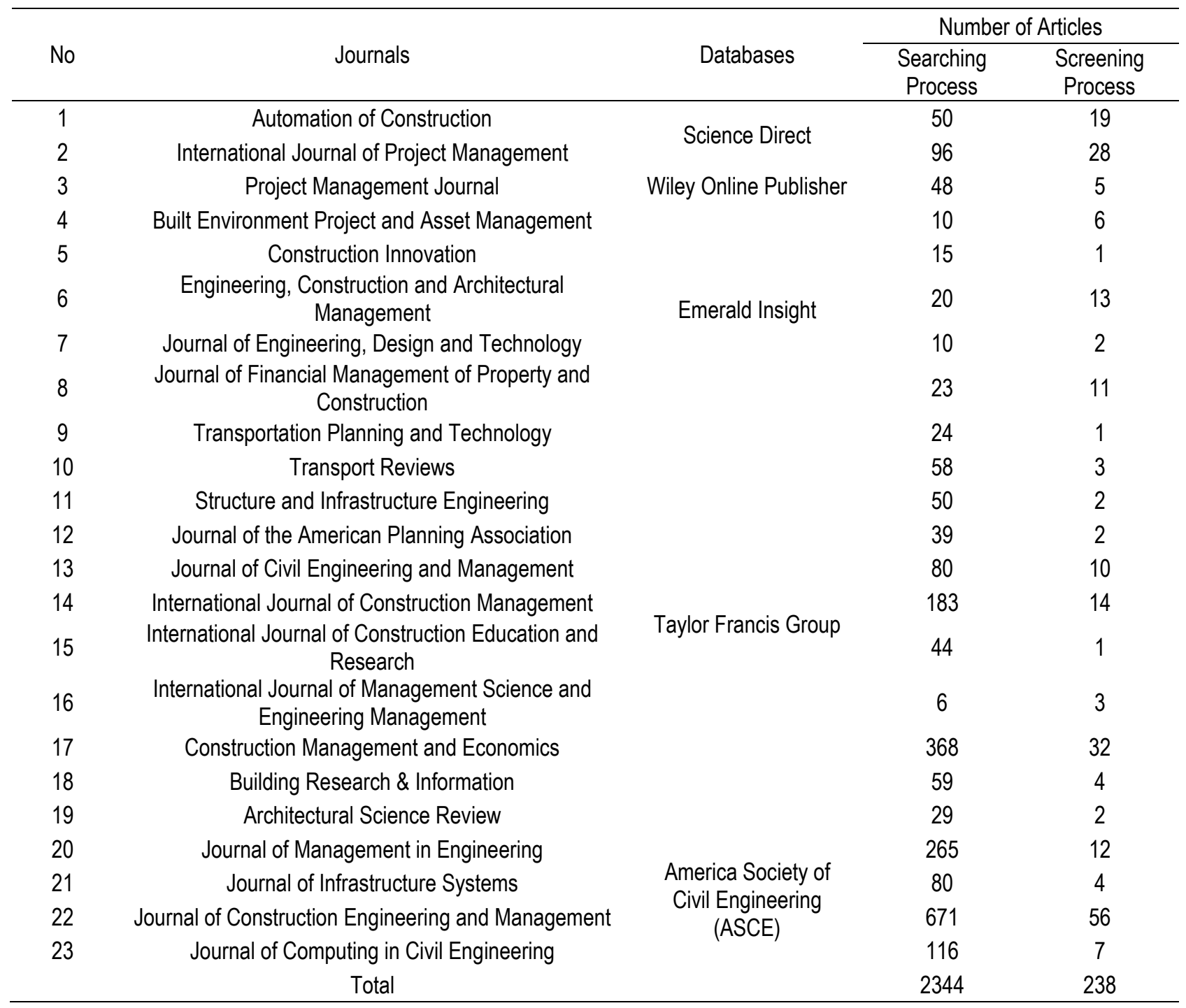

\section{Eligibility}

In this step, the screening process articles were subjected to a further eligibility process to assess the quality. This process requires a visual examination of all 238 articles to achieve significant articles related to this research topic. After the eligibility process, the numbers of articles were reduced to 33, with details shown in Error! Reference source not found. 
Table 2. Total articles after screening and eligibility process

\begin{tabular}{|c|c|c|c|c|}
\hline \multirow[b]{2}{*}{ No } & \multirow[b]{2}{*}{ Journals } & \multirow[b]{2}{*}{ Databases } & \multicolumn{2}{|c|}{ Number of Articles } \\
\hline & & & $\begin{array}{l}\text { Screenin } \\
\text { g Process }\end{array}$ & $\begin{aligned} \text { Eligibilit } \\
\text { y Process }\end{aligned}$ \\
\hline 1 & Automation of Construction & \multirow[b]{2}{*}{ Science Direct } & 19 & 0 \\
\hline 2 & $\begin{array}{c}\text { International Journal of Project } \\
\text { Management }\end{array}$ & & 28 & 4 \\
\hline 3 & Project Management Journal & \multirow[t]{2}{*}{ Wiley Online Publisher } & 5 & 0 \\
\hline 4 & $\begin{array}{c}\text { Built Environment Project and Asset } \\
\text { Management }\end{array}$ & & 6 & 2 \\
\hline 5 & Construction Innovation & \multirow{4}{*}{ Emerald Insight } & 1 & 0 \\
\hline 6 & $\begin{array}{l}\text { Engineering, Construction and } \\
\text { Architectural Management }\end{array}$ & & 13 & 3 \\
\hline 7 & $\begin{array}{c}\text { Journal of Engineering, Design and } \\
\text { Technology }\end{array}$ & & 2 & 1 \\
\hline 8 & $\begin{array}{l}\text { Journal of Financial Management of } \\
\text { Property and Construction }\end{array}$ & & 11 & 4 \\
\hline 9 & $\begin{array}{c}\text { Transportation Planning and } \\
\text { Technology }\end{array}$ & \multirow{10}{*}{ Taylor Francis Group } & 1 & 0 \\
\hline 10 & Transport Reviews & & 3 & 0 \\
\hline 11 & Structure and Infrastructure Engineering & & 2 & 0 \\
\hline 12 & $\begin{array}{c}\text { Journal of the American Planning } \\
\text { Association }\end{array}$ & & 2 & 2 \\
\hline 13 & $\begin{array}{l}\text { Journal of Civil Engineering and } \\
\text { Management }\end{array}$ & & 10 & 0 \\
\hline 14 & $\begin{array}{c}\text { International Journal of Construction } \\
\text { Management }\end{array}$ & & 14 & 2 \\
\hline 15 & $\begin{array}{l}\text { International Journal of Construction } \\
\text { Education and Research }\end{array}$ & & 1 & 0 \\
\hline 16 & $\begin{array}{l}\text { International Journal of Management } \\
\text { Science and Engineering Management }\end{array}$ & & 3 & 1 \\
\hline 17 & $\begin{array}{c}\text { Construction Management and } \\
\text { Economics }\end{array}$ & & 32 & 10 \\
\hline 18 & Building Research \& Information & & 4 & 0 \\
\hline 19 & Architectural Science Review & \multirow{6}{*}{$\begin{array}{c}\text { America Society of } \\
\text { Civil Engineering (ASCE) }\end{array}$} & 2 & 0 \\
\hline 20 & Journal of Management in Engineering & & 12 & 1 \\
\hline 21 & Journal of Infrastructure Systems & & 4 & 0 \\
\hline 22 & $\begin{array}{c}\text { Journal of Construction Engineering and } \\
\text { Management }\end{array}$ & & 56 & 3 \\
\hline \multirow[t]{2}{*}{23} & $\begin{array}{l}\text { Journal of Computing in Civil } \\
\text { Engineering }\end{array}$ & & 7 & 0 \\
\hline & Total & & 238 & 33 \\
\hline
\end{tabular}

\section{Summarizing}

The summarising step focuses on analyzing and synthesizing the papers selected in the eligibility stage to derive a theoretical explanation of the factors that influence cost estimation performance. The analysis process was qualitative and was interpreted attentively. The shortlisted articles were carefully organized and classified into the research focus and theme appropriately. The synthesized theme was cost estimation performance, practices of cost estimation performance, and cost estimation methods used to improve cost estimation performance. The summary and trend of the 33 shortlisted articles were further discussed in the form of Overall Time Span (Figure 2), Overall Journal Shares (Figure 3), and Distribution across Countries (Figure 4).

\section{Overall time span}

The tabulation of the factors of cost estimation performance-related papers was shown in Figure 2. The paper has been published since 1989 with only one article and continued to increase in 1991 ( 2 papers) and 1994 ( 3 papers). After that, the number of published papers decreased in 2000, 2001 and 2002. In 2005, the selected papers published were found to 
be the highest with five papers, and the related papers started to decrease in 2006 with one paper. From 2006 to 2020 , the number of papers fluctuated between one and two papers. The overall trend indicated a constant low of published articles about factors of cost estimation performance after 2005.

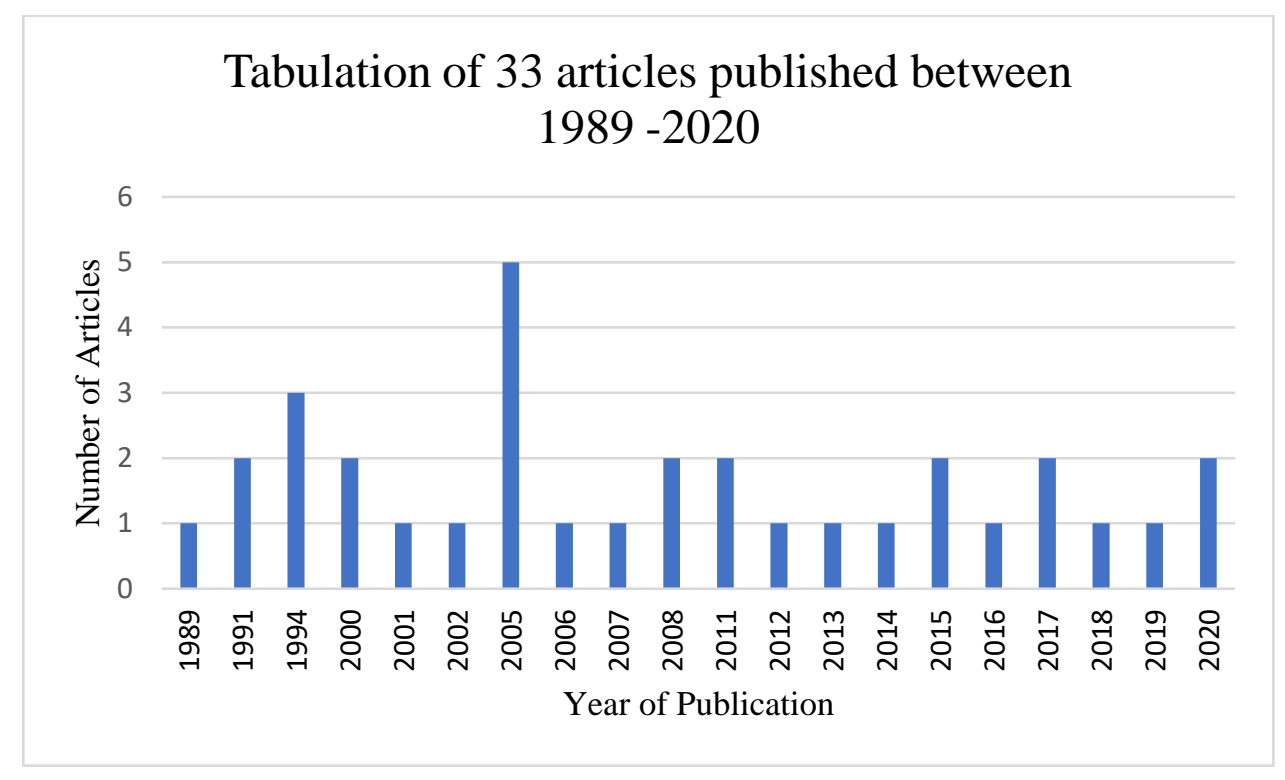

Figure 2. Tabulation of 33 articles published between 1989-2020

\section{Overall journal shares}

In Figure 3, the 33 papers were categorized according to their journal respectively. Construction Management and Economics published the highest number of papers (10 papers), followed by Journal of Financial Management of Property and Construction (4 papers) and International Journal of Project Management (4 papers). Despite that, the three journals that published the least factors of cost estimation performance-related papers were Journal of Management in Engineering (1 paper), Journal of Engineering, Design and Technology (1 paper) and International Journal of Management Science and Engineering Management (1 paper).

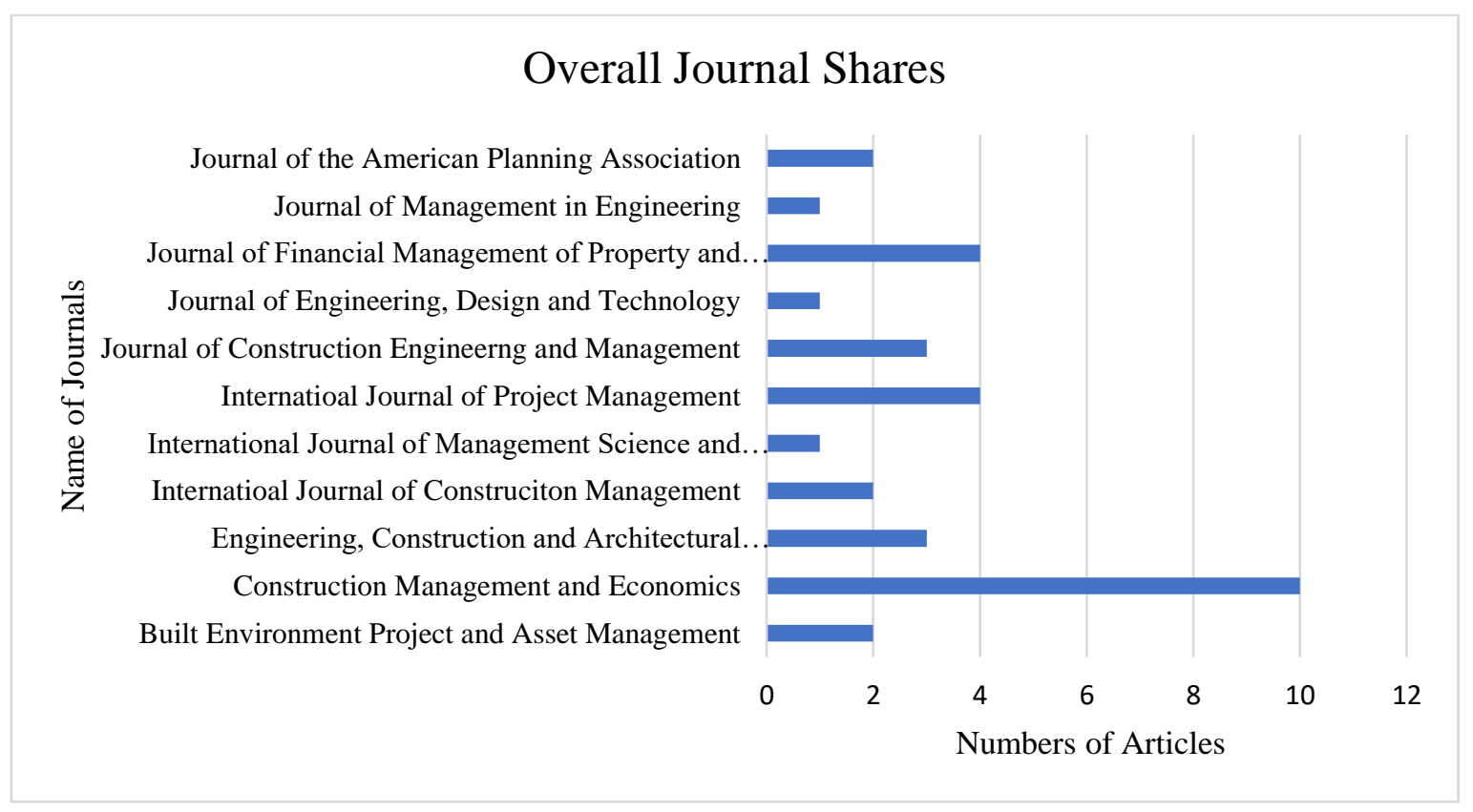

Figure 3. The journal shares 33 selected papers 


\section{Distribution across countries percentage}

The papers about factors of cost estimation performance varied across countries which were shown in Figure 4 . The country that has the highest number of the selected papers was U.K. (10 papers, 32\%), followed by U.S.A. (4 papers, 13\%), and Australia (4 papers, 13\%). Countries like Saudi Arabia and Malaysia have the lowest number of articles published which were one paper respectively.

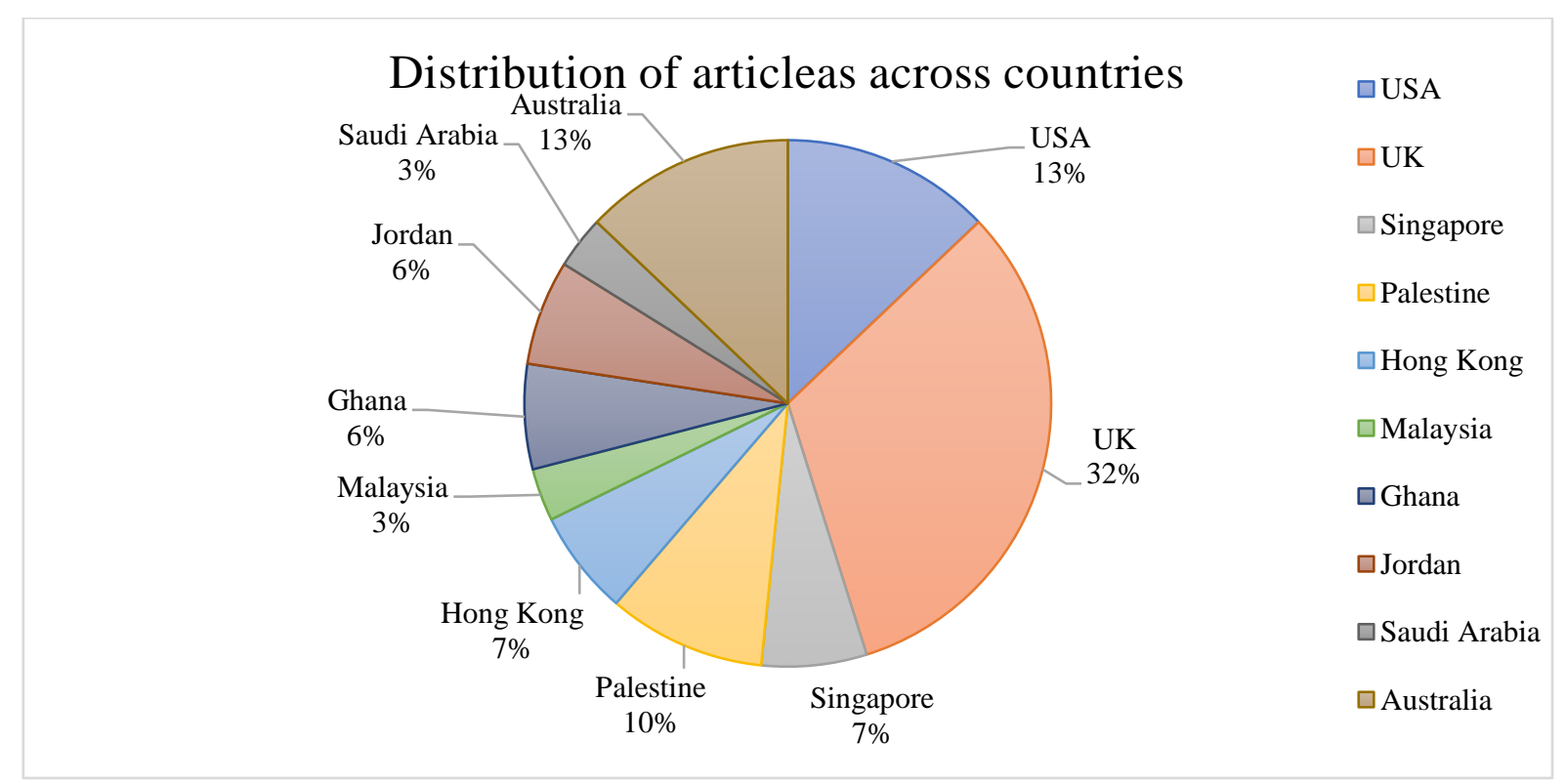

Figure 4. Distribution of articles across countries

\section{Interpreting}

In this stage, the extracted 33 articles related to cost estimation performance were synthesized and categorized in dimensions such as input control, behavior control, output control, project complexity, task characteristic, and technology characteristic. The future research direction on cost estimation performance is determined by using the evidence's strengths and weaknesses.

\section{DISCUSSION}

\section{Finding of the systematic review}

This paper evaluates construction cost estimation articles published in journals and helps support other construction cost estimation researchers through a classification of cost estimation performance's factors to new shared dimensions and future research direction on construction cost estimation based on organization control theory (OCT), contingency theory (C.T.) and task-technology fit theory (TTFT).

Firstly, some factors of cost estimation performance were clustered into control dimensions which are input control, behavior control and output control based on OCT. Other factors were clustered into task characteristic and technology characteristic, according to TTFT. Project complexity was the last dimension in which the most factors were clustered. The factors of cost estimation performance were summarized and clustered into shared dimensions which are shown in Table 3.

Table 3: Overall summary of cost estimation performance factors

\begin{tabular}{|c|c|c|}
\hline $\begin{array}{c}\text { Shared } \\
\text { Dimensions }\end{array}$ & Factors & Authors \\
\hline \multirow[t]{2}{*}{$\begin{array}{l}\text { Input } \\
\text { Control }\end{array}$} & Project Information & $\begin{array}{c}\text { Aibinu \& Pasco (2008), Akintoye (2000), Akintoye \& } \\
\text { Fitzgerald (2000), Al-Harbi et al. (1994), Chan \& Park (2005), } \\
\text { Doloi (2013), Enshassi et al. (2005), Hatamleh et al. (2018), Jing } \\
\text { et al. (2019) }\end{array}$ \\
\hline & Cost Information & $\begin{array}{c}\text { Agyekum-Mensah (2018), Aibinu \& Pasco (2008), } \\
\text { Akinradewo et al. (2020), Akintoye (2000), Akintoye \& } \\
\text { Fitzgerald (2000), Carr (1989), Chan \& Park (2005), Flyvbjerg et }\end{array}$ \\
\hline
\end{tabular}




\begin{tabular}{|c|c|}
\hline $\begin{array}{c}\text { Shared } \\
\text { Dimensions }\end{array}$ & Factors \\
\hline \multirow{4}{*}{$\begin{array}{l}\text { Behavior } \\
\text { Control }\end{array}$} & Team Experience \\
\hline & Estimation Design \\
\hline & Estimation Process \\
\hline & $\begin{array}{l}\text { Resources } \\
\text { Integration }\end{array}$ \\
\hline \multirow[t]{2}{*}{$\begin{array}{l}\text { Output } \\
\text { Control }\end{array}$} & $\begin{array}{c}\text { Review and } \\
\text { Acceptance of a review }\end{array}$ \\
\hline & $\begin{array}{c}\text { Benchmarking and } \\
\text { Expected accuracy } \\
\text { level }\end{array}$ \\
\hline $\begin{array}{c}\text { Task } \\
\text { Characteristic }\end{array}$ & $\begin{array}{l}\text { Variation in Task } \\
\text { (magnitude, timing, } \\
\text { interference level) }\end{array}$ \\
\hline $\begin{array}{l}\text { Technology } \\
\text { Characteristic }\end{array}$ & $\begin{array}{l}\text { Cost estimation } \\
\text { methods used }\end{array}$ \\
\hline $\begin{array}{r}\text { Project } \\
\text { Complexity }\end{array}$ & $\begin{array}{l}\text { Project Risk \& } \\
\text { Uncertainty }\end{array}$ \\
\hline
\end{tabular}

\section{Project Size}

The environment of changing policy and regulation

The environment of changing economy al. (2002), Hatamleh et al. (2018), Lim et al.(2016), Morrison

(2006)

Agyekum-Mensah (2018), Akinradewo et al. (2020), Akintoye (2000), Akintoye \& Fitzgerald (2000), Al-Harbi et al. (1994), Carr (1989) Chan \& Park (2005), Dandan et al. (2019), Dulaimi \& Shan (2002), Elhag et al. (2005), Flyvbjerg et al. (2002), Grau et al. (2017), Hatamleh et al. (2018), Islam et al. (2019), Jing et al. (2019), Leung et al. (2005), Lowe \& Skitmore (1994), Mahamid (2015), Ogunlana (1991), Trost \& Oberlender (2003)

Akinradewo et al. (2020), Akintoye (2000), Akintoye \& Fitzgerald (2000), Al-Harbi et al. (1994), Elhag et al. (2005), Enshassi et al. (2005), Islam et al. (2019), Morrison (2006), Soutos \& Lowe (2011), Uher (1996)

Aibinu \& Pasco (2008), Akinradewo et al. (2020), Akinradewo et al. (2020), Al-Harbi et al. (1994), Dandan et al. (2019), Grau et al., (2017), Hatamleh et al. (2018), Oberlender \& Trost (2001)

Akinradewo et al. (2020), Akinradewo et al. (2020), Akintoye \& Fitzgerald (2000), Al-Harbi et al. (1994), Chan \& Park (2005), Dulaimi \& Shan (2002), Grau et al. (2017), Mahamid (2015) Oberlender \& Trost (2001)

Aibinu \& Pasco (2008), Akinradewo et al. (2020), Akintoye \& Fitzgerald (2000), Grau et al. (2017)

Aibinu \& Pasco (2008), Akinradewo et al. (2020), Akinradewo et al. (2020), Flyvbjerg et al. (2005)

Agyekum-Mensah (2018), Akintoye (2000), Chan \& Park (2005), Dandan et al. (2019), Enshassi et al. (2005)

Agyekum-Mensah (2018), Akintoye (2000), Chan \& Park (2005) Dandan et al. (2019)

Agyekum-Mensah (2018), Aibinu \& Pasco (2008), Lim et al. (2016), Oberlender \& Trost (2001), Sridarran et al. (2017), Tah et al. (1994), Uher (1996)

Akinradewo et al. (2020), Arif et al. (2015), Jørgensen et al. (2012) Sridarran et al. (2017)

Akintoye \& Fitzgerald (2000), Al-Harbi et al. (1994), Doloi (2011), Dulaimi \& Shan (2002), Enshassi et al. (2005), Flyvbjerg et al. (2002), Mahamid (2015), Oberlender \& Trost (2001), Sridarran et al. (2017)

Agyekum-Mensah (2018), Aibinu \& Pasco (2008), Akinradewo et al. (2020), Akinradewo et al. (2020), Al-Harbi et al. (1994), Carr (1989), Dandan et al. (2019), Doloi (2011), Dulaimi \& Shan (2002), Elhag et al. (2005), Flyvbjerg et al. (2005), Hatamleh et al. (2018), Mahamid (2015), Sridarran et al. (2017) 


\begin{tabular}{ccc} 
Shared & Factors & Authors \\
Dimensions & & \\
\hline
\end{tabular}

Change in the project construction environment

\author{
External \\ stakeholder influence
}

The complexity of the contractual relationship
Akinradewo et al. (2020), Akinradewo et al. (2020), Akintoye (2000), Akintoye \& Fitzgerald (2000), Al-Harbi et al. (1994), Arif et al. (2015), Doloi (2011), Enshassi et al. (20050, Flyvbjerg et al. (2002), Hatamleh et al. (2018), Mahamid (2015)

Akintoye (2000), Akintoye \& Fitzgerald (2000), Al-Harbi et al. (1994), Arif et al. (2015), Chan \& Park (2005), Dandan et al. (2019), Doloi (2013), Enshassi et al. (2005), Flyvbjerg et al. (2002), Grau et al. (2017), Hatamleh et al. (2018), Mahamid

(2015) Oberlender \& Trost (2001), Sridarran et al. (2017)

Agyekum et al. (2018), Akintoye (2000), Akintoye \& Fitzgerald (2000), Al-Harbi et al. (1994), Chan \& Park (2005), Dulaimi \& Shan (2002), Elhag et al. (2005), Enshassi et al. (2005), Mahamid (2015), Oberlender \& Trost (2001)

According to the systematic review, the factors were clustered into six main themes: input control, behavior control, output control, project complexity, task characteristic, and technology characteristic. Each of the themes is discussed below for a better understanding of the attribute of the themes.

\section{Input Control}

Input control is defined as the people resource-related factors that influence performance specifically the knowledge, skills, abilities, values, and motives of employees (Snell, 1992). In this paper, input control not only regulates input related factors in the perspective of human but also information into transformation processes. From the systematic review, the input control relates to the experience of estimators, project team and stakeholders, project information such as project scope and specification, and cost information in term of historical data of similar project and material price. These input factors may be gained through mechanisms by selecting the proper people and improving data quality. Previous studies frequently involved input control with motives, skills, abilities, and experience of employees (Snell, 1992). Keltner and Finegold (1996) considered input control as direction setting, selection of criteria for staffs and promotion. Liu and Zhu (2007) involved information special cost and project information in his input control dimension.

\section{Behavior Control}

Behavior Control is defined when a leader demands certain behaviors, explicit procedures, or rules for the controlee, and the performance of the controlees are monitored and evaluated according to specified behaviors or procedures (Turner \& Makhija, 2006). In other words, behavior control focuses on securing proper behavior, which provides the targeted results. After the processes of systematic review, behavior control includes time given in completing estimation, estimation design, estimation processes, and resource integration among stakeholders. Sihag and Rijsdijk (2019) utilized a detailed procedure of techniques as a mechanism of behavior control if it articulates the precise steps to follow to improve individual performance.

\section{Output Control}

Output Control is referred to performance outputs, standards or goals, and the performance of the controlees are monitored and evaluated according to those outputs or goals (Kirsch et al., 2004). In other words, output control specifies the targeted outputs or objectives, if people with the target will adopt proper behavior to achieve them. After the review processes, output control involves expected estimation accuracy, acceptance of review and benchmarking. Liu and Zhu (2007) considered expected accuracy level, review and acceptance of estimate and benchmarking in his output control dimension.

\section{Task Characteristic}

Tasks are indicated by the totality of physical and cognitive actions and processes done by individuals in a given environment (Spies et al., 2020). Task characteristic is defined as a feature of entire physical or cognitive actions and processes performed by individuals in a certain environment (Goodhue \& Thompson, 1995). Task characteristic theme covers the type of tasks in cost estimation such as repeated task, special requirement task and variation of magnitude, 
timing, interference in tasks. In cost estimation, many technologies are used in order to estimate task completion with ease.

\section{Technology Characteristic}

Technology refers to a tool that is used to perform or assist in performing the given tasks by individuals (Goodhue \& Thompson, 1995). The technology characteristics are aligned with task characteristic discussion which have various definition according to the researcher with concern to the surrounding where it utilized and the tasks that required its assistance (Spies et al., 2020). The theme or dimension of technology characteristic involves the characteristic of cost estimation methods that are utilized in completing estimating tasks.

\section{Project complexity}

Project complexity is defined as a group of problems contain a multitude of possible interrelations which associate with a high consequence in the decision-making process that come out with the outcome (Girmscheid, C., \& Brockmann, 2008). From the finding of the systematic review, the project complexity dimension covers many factors of cost estimation performance especially project-related factors such as project risk, project uncertainty, project contingency, and project size. Furthermore, the dimension also consists of external related factors such as political situation, economic condition, market condition, external stakeholder (contractors and consultant), and complexity in contractual related factors. Luo et al. (2017) utilized information complexity, task complexity, technology complexity, organizational complexity, environmental complexity, and goal complexity as factors to project complexity construct. Yang and Cheng (2021) applied project complexity as a moderator for the relationship between relational governance and opportunism and project performance. In this study, the project complexity was influenced by project uncertainty, technical level, and the number of outsourcers and stakeholders.

\section{Predominately Used Theories}

In this paper, theories such as Organizational Control Theory (OCT), Contingency Theory (CT) and Task-Technology Fit Theory (TTFT) were utilized and adopted in developing a new framework towards cost estimation performance. These theories were used to classify the factors of cost estimation performance and describe the relationships among the factors including the relationship with cost estimation performance.

TTFT indicates that information technology (IT) has a high probability to give a positive impact on individual performance and can be used if the capabilities of the IT have high compatibility with the task given to the user (Goodhue \& Thompson, 1995). According to TTFT, individual performance can be predicted by task-technology fit. The fit consists of eight factors which are quality, locatability, authorisation, compatibility, ease of use/training, production timeliness, system reliability, and relationship with users (Goodhue \& Thompson, 1995) The fit is formed through a composition of task characteristic and technology characteristic. Task-technology fit measures the degree of compatibility between task and technology characteristics (Farr, 1974). The dynamics of TTFT that affect an individual performance can be systematically mapped as Figure 5.

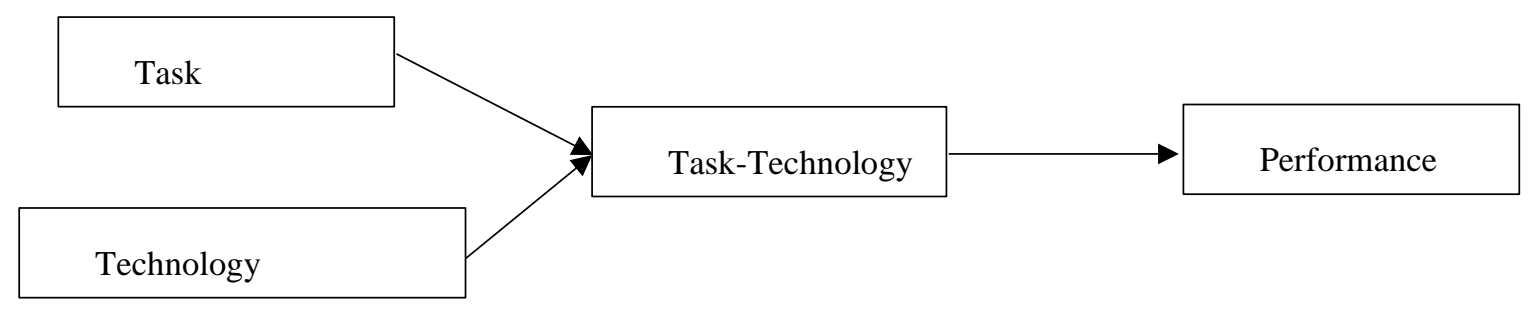

Figure 5: Task-Technology Fit Theory

Many previous studies utilized TTFT in the information system. The theory is used to predict individual performance based on the compatibility of the information system and the user's tasks.

Organizational control theory involves exploring the action of a party towards another party that affects their behaviors. It also comprises verbal and physical communication actions to overwhelm others' resistance and authority (Littlejohn et al., 2012). The dominant model of organizational control theory was developed by Ouchi (1979) through analyzing the prerequisite that governs the application of output and behavior controls. The model is shown in Table 4 with the availability of output measures (output measurability) and knowledge of transformation processes (task programmability) as dimensions (Ouchi, 1979). 
Table 4: Choice of organizational control mode

\begin{tabular}{cccc}
\hline & & \multicolumn{2}{c}{ Task Programmability } \\
\cline { 3 - 4 } & & High & Low \\
\hline Output Measurability & High & Behavior & Output \\
& & Control or Output & Control \\
& & Control & \\
& Low & Behavior & Input \\
& & Control & Control \\
\hline
\end{tabular}

The model predicts the choice of managers in the control modes. It is possible to determine the suited behavior to achieve the desired outcomes if the involved tasks are well understood. In this condition, behavior control is suitable to use. It is appropriate to utilize output control when the results are measured, observed and controlled easily. When these conditions cannot be applied, input control should be used. Organizational control usually is applied in the context of information systems development (ISD) projects (Henderson \& Lee, 1992; Kirsch, 1997) and outsourced ISD projects (Choudhury \& Sabherwal, 2003; Kirsch et al., 2002).

A contingency theory is an organizational theory that assumes that there is no best way to organize an organization (Williamson \& Chandler, 1964). However, the appropriate action depends on the internal and external situation (Williamson \& Chandler, 1964). The basic contingency theory is based on the system approach, which recognized as a famous tool for understanding organization in the 1950s. The main feature of the open system approach is that it refers to the larger environment selected as a context for understanding an organization's activities (Coates \& Horngren, 1966). The contingency theory was currently developed based on sociological functionalist theories such as the structural approaches to organizational studies (Chenhall, 2003; Reid \& Smith, 2000; Woods, 2009). These studies explained that organizational characteristic was contingent on contextual factors such as technology, task environment and organizational size. Contingency theory has been utilized in project management and cost estimation (Howell et al., 2010; Woods, 2009). The general relationship of the theory can be systematically mapped as Figure 6 by adding a moderator effect of project complexity.

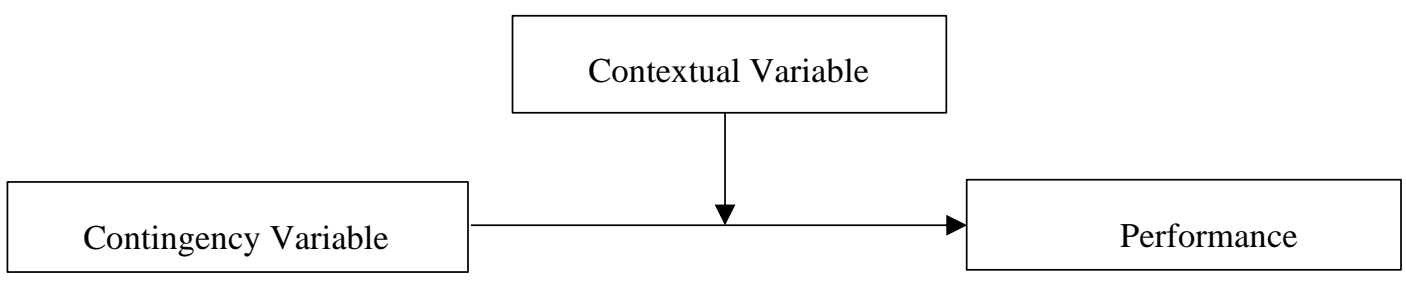

Figure 6: Contingency Theory

\section{Future Directions}

Based on the systematic review, several research gaps were identified in the factors of cost estimation performance:

1. Most of the factors were clustered based on Organizational Control Theory (OCT) which are input control, behaviour control and output control. However, Akintoye (2000) and Sridarran et al. (2017) concluded that the control factors were not the only primary factors that influence cost estimation performance such as external factors which include project characteristics, external stakeholder, market and economic conditions.

2. The correlations among the factors are fragmented, and the relationship between input control, behaviour control, output control, project complexity, task characteristic, and technology characteristic is unknown and unrecognised. Furthermore, a model is still not developed regarding cost estimation performance.

From the review, various type of tasks and technologies affect the cost estimation performance. The task characteristics and technology characteristics posited by TTFT can be adopted from a cost estimation perspective. As technology refers to a tool that is used to perform or assist in performing the given tasks by individuals (Ammenwerth et al., 2006), technology characteristic in TTFT is adopted to the characteristic of cost estimation methods. Cost estimation methods frequently assist estimators in completing the task of cost estimation. This provides a theoretical base to explain the first research gap by integrating task and technology factors.

Moreover, contingency theory is used to govern the relationship of control factors and cost estimation performance. Previous studies that link relationship control factors and performance have significant and insignificant findings as shown in Table 5.

Contradictions in the findings provide an opportunity to adopt contingency theory to explain the dynamic relationship between the control factors and cost estimation performance. The project complexity is used as a contextual variable in the contingency theory which affects as a moderator in the relationship between control factors and cost estimation performance. 
Table 5: Previous studies on control and performance

\begin{tabular}{ccc}
\hline \multirow{2}{*}{ Control Mode } & \multicolumn{2}{c}{ Effect on Performance } \\
\cline { 2 - 3 } & Significant & Insignificant \\
\hline Input Control & Yu \& To, (2011) & Bonner et al. (2002) \\
Behavior Control & Henderson and Lee (1992) & Gopal \& Gosain, (2010) \\
Output Control & Tiwana, (2010) & Henderson \& Lee, (1992) \\
\hline
\end{tabular}

In conclusion, these theories are appropriate for explaining the second research gap, which the unknown relationships among factors of cost estimation performance and cost estimation performance. The application of the theories is to reestablish and reclassify the existing factors of cost estimation into TTFT, OCT and CT constructs. The integration between TTFT, OCT, and CT provides a better understanding of cost estimation performance in construction projects. The dynamism of the relationships among the factors and the performance variable is systematically mapped in Figure 7.

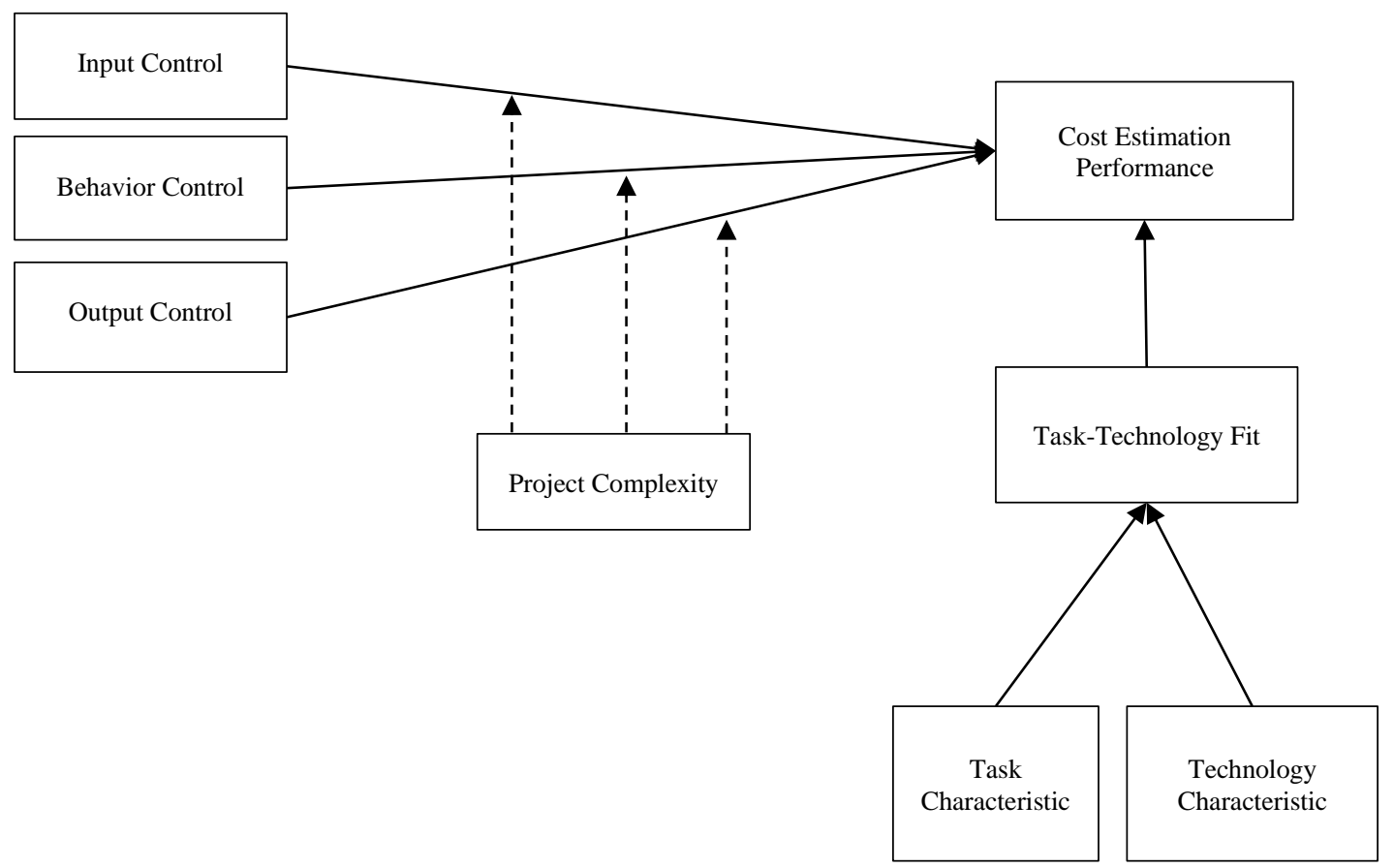

Figure 7: The integration between TTFT and CT in explaining cost estimation performance

This study will not only contribute to the knowledge theoretically but also practically. The findings of this study provide a better understanding of the factors that influence cost estimation performance. Therefore, it will improve the performance of estimating cost and leads to less cost and time overrun to occur in the construction projects. Hence, it will provide the best platform for the construction project to be successful.

Furthermore, the model will help the project manager in decision-making regarding what cost estimation methods to utilize in the construction project. The decision is made based on the effectiveness of the method of cost estimation toward the task required in the projects as different cost estimation method has different effects in terms of accuracy, application and ease to understand (Jonny Klakegg et al., 2010).

The study also helps the project manager to specify control modes to utilize in the project teams. As an organization is responsible to provide an appropriate environment for staffs to perform better (Litzky et al., 2006), appropriate control modes applied will provide a better condition for the staffs to perform in high productivity. Thus, this will improve the overall performance of cost estimation. However, the effectiveness of control modes can vary according to the degree of project complexity. This study provides assistance for the project manager to utilize the control modes effectively and efficiently in the high or low complexity of a project.

\section{CONCLUSION}

This paper's primary objectives are to synthesize the factors that are affecting cost estimation performance in construction projects and propose future directions regarding cost estimation performance based on the identified factors. The objectives were achieved by performing a systematic review in 11 predefined journals. The search processes of the systematic review were conducted by using predefined keywords in the domain of Title, Article, and Abstract. Then, the selected articles were synthesized according to factors of cost estimation performance. 33 related articles were identified, 
which have been published between 1989 and 2020. The overall trend indicated that the importance of cost estimation performance's factors lacked researchers' attention after 2005.

Through the full-text review of the papers, the cost estimation performance factors were identified and clustered accordingly. The identified factors were clustered into six themes, such as input control, behavior control, output control, project complexity, task characteristic, and technology characteristic. Nevertheless, the relationship among the factors is unknown.

From the systematic literature review, most of the selected control-related factors were classified according to organizational control theory (input, behavior, and output). As the relationship of the factors with cost estimation performance is fragmented, there is a research gap for the relationships to be conceptualized with theoretical constructs.

This study used contingency and task-technology fit theories to respond to the identified research gap. The predefined shared dimensions were re-categorized under input control, behavior control, output control, project complexity, task characteristic, and technology characteristic constructs. The constructs of OCT, CT and TTFT integration provide capabilities to explain the relationship among the factors and towards cost estimation performance.

Despite these theories' capabilities, the application of the theories in knowledge areas of cost estimation performance is novel. Therefore, it contributes to some future direction of the research regarding cost estimation performance. Hence, future research's key objective is to recommend how the OCT, CT and TTFT theories can be utilized to predict and explain cost estimation performance in construction projects.

Furthermore, the TTFT and CT were integrated to predict the cost estimation performance. The integration of these theories provides a better understanding of the relationship's dynamism among the factors.

In conclusion, researchers have yet to investigate a cost estimation performance through these theories. This study provides a better understanding of cost estimation performance and significance for practitioners and academics. It also offers an opportunity to further research in cost estimation areas by utilizing introduced theories. Thus, it provides a contribution to the research area of cost estimation practically and theoretically.

\section{ACKNOWLEDGEMENT}

The author is grateful to the anonymous reviewers of this paper.

\section{REFERENCES}

Agyekum - Mensah, G. (2019). The degree of accuracy and factors that influence the uncertainty of SME cost estimates. International Journal of Construction $\quad$ Management, $\quad 19(5), \quad 413-426$. https://doi.org/10.1080/15623599.2018.1452094

Agyekum, B., Kissi, E., Yamoah Agyemang, D., \& Badu, E. (2018). Examining barriers for the utilization of nontraditional cost estimating models in developing countries: Ghanaian quantity surveyors' perspectives. Journal of Engineering, Design and Technology, 16(6), 814-827. https://doi.org/10.1108/JEDT-02-2018-0021

Aibinu, A. A., \& Pasco, T. (2008). The accuracy of pre-tender building cost estimates in Australia. Construction Management and Economics, 26(12), 1257-1269. https://doi.org/10.1080/01446190802527514

Akinradewo, O., Aigbavboa, C., \& Oke, A. (2020). Accuracy of road construction preliminary estimate: examining the influencing factors. Built Environment Project and Asset Management, 10(5), 657-671. https://doi.org/10.1108/BEPAM-11-2019-0101

Akinradewo, O. I., Aigbavboa, C. O., \& Oke, A. E. (2020). Improving accuracy of road projects' estimates in the Ghanaian construction industry. Journal of Financial Management of Property and Construction, 25(3), $407-421$. https://doi.org/10.1108/JFMPC-11-2019-0087

Akintoye, A. (2000). Analysis of factors influencing project cost estimating practice. Construction Management and Economics, 18(1), 77-89. https://doi.org/10.1080/014461900370979

Akintoye, A., \& Fitzgerald, E. (2000). A survey of current cost estimating practices in the UK. Construction Management and Economics, 18(2), 161-172. https://doi.org/10.1080/014461900370799

Al-Harbi, K. M., Johnston, D. W., \& Fayadh, H. (1994). Building Construction Detailed Estimating Practices in Saudi Arabia. Journal of Construction Engineering and Management, 120(4), $774-784$. https://doi.org/10.1061/(asce)0733-9364(1994)120:4(774)

Ammenwerth, E., Iller, C., \& Mahler, C. (2006). IT-adoption and the interaction of task, technology and individuals: A fit framework and a case study. BMC Medical Informatics and Decision Making, 6(1), 3. https://doi.org/10.1186/1472-6947-6-3

Arif, F., Lodi, S. H., \& Azhar, N. (2015). Factors influencing accuracy of construction project cost estimates in Pakistan: Perception and reality. International Journal of Construction Management, 15(1), 59-70. https://doi.org/10.1080/15623599.2015.1012141

Aziz, R. F. (2013). Ranking of delay factors in construction projects after Egyptian revolution. Alexandria Engineering Journal, 52(3), 387-406. https://doi.org/10.1016/j.aej.2013.03.002

Barakchi, M., Torp, O., \& Belay, A. M. (2017). Cost Estimation Methods for Transport Infrastructure: A Systematic Literature Review. Procedia Engineering, 196, 270-277. https://doi.org/10.1016/j.proeng.2017.07.199

Bonner, J. M., Ruekert, R. W., \& Walker, O. C. (2002). Upper management control of new product development projects and project performance. Journal of Product Innovation Management, 19(3), $233-245$. 
https://doi.org/10.1016/S0737-6782(02)00139-X

Carr, R. I. (1989). Cost-Estimating Principles. Journal of Construction Engineering and Management, 115(4), 545-551. https://doi.org/10.1061/(asce)0733-9364(1989)115:4(545)

Chan, S. L., \& Park, M. (2005). Project cost estimation using principal component regression. Construction Management and Economics, 23(3), 295-304. https://doi.org/10.1080/01446190500039812

Chenhall, R. H. (2003). Management control systems design within its organizational context: Findings from contingency-based research and directions for the future. Accounting, Organizations and Society, 28(2-3), 127168. https://doi.org/10.1016/S0361-3682(01)00027-7

Choudhury, V., \& Sabherwal, R. (2003). Portfolios of Control in Outsourced Software Development Projects. Information Systems Research, 14(3), 291-314. https://doi.org/10.1287/isre.14.3.291.16563

Coates, J. B., \& Horngren, C. T. (1966). Accounting for Management Control: An Introduction. In or (Vol. 17, Issue 4, p. 480). Springer. https://doi.org/10.2307/3007453

Dandan, T. H., Sweis, G., Sukkari, L. S., \& Sweis, R. J. (2019). Factors affecting the accuracy of cost estimate during various design stages. Journal of Engineering, Design and Technology, 18(4), 787-819. https://doi.org/10.1108/JEDT-08-2019-0202

Doloi, H. (2013). Cost Overruns and Failure in Project Management: Understanding the Roles of Key Stakeholders in Construction Projects. Journal of Construction Engineering and Management, 139(3), $267-279$. https://doi.org/10.1061/(asce)co.1943-7862.0000621

Doloi, H. K. (2011). Understanding stakeholders' perspective of cost estimation in project management. International Journal of Project Management, 29(5), 622-636. https://doi.org/10.1016/j.ijproman.2010.06.001

Du, J., Wang, Q., \& Shi, Q. (2019). Description-experience gap under imperfect information: Information continuum and aggressive cost estimating in capital projects. Engineering, Construction and Architectural Management, 26(6), 1151-1170. https://doi.org/10.1108/ECAM-02-2018-0075

Dulaimi, M. F., \& Shan, H. G. (2002). The factors influencing bid mark-up decisions of large- and medium-size contractors in Singapore. Construction Management and Economics, 20(7), 601-610. https://doi.org/10.1080/01446190210159890

Elhag, T. M. S., Boussabaine, A. H., \& Ballal, T. M. A. (2005). Critical determinants of construction tendering costs: Quantity surveyors' standpoint. International Journal of Project Management, 23(7), 538-545. https://doi.org/10.1016/j.ijproman.2005.04.002

Enshassi, A., Mohamed, S., \& Madi, I. (2005). Factors affecting accuracy of cost estimation of building contracts in the Gaza Strip. Journal of Financial Management of Property and Construction, 10(2), 115-125. https://doi.org/10.1108/13664380580001069

Farr, J. L. (1974). Designing Complex Organizations (Book). In Personnel Psychology (Vol. 27, Issue 2). AddisonWesley Longman Publishing Co., Inc. http://content.ebscohost.com/ContentServer.asp?T=P\&P=AN\&K=6260925\&S=R\&D=bth\&EbscoContent=dGJy MNLe80Sepq84wtvhOLCmr0meprBSsqy4TLeWxWXS\&ContentCustomer=dGJyMPGuslGvqrdKuePfgeyx44Dt 6fIA

Flyvbjerg, B., Holm, M. S., \& Buhl, S. (2002). Underestimating costs in public works projects: Error or lie? Journal of the American Planning Association, 68(3), 279-295. https://doi.org/10.1080/01944360208976273

Flyvbjerg, B., Skamris Holm, M. K., \& Buhl, S. L. (2005). How (In)accurate are demand forecasts in public works projects?: The case of transportation. Journal of the American Planning Association, 71(2), $131-146$. https://doi.org/10.1080/01944360508976688

Girmscheid, C., \& Brockmann, G. (2008). The Inherent Complexity of Large Scale Engineering Projects. International Project Management Association, 29, 22-26., 29, 22-26.

Goodhue, D. L., \& Thompson, R. L. (1995). Task-technology fit and individual performance. MIS Quarterly: Management Information Systems, 19(2), 213-233. https://doi.org/10.2307/249689

Gopal, A., \& Gosain, S. (2010). The role of organizational controls and boundary spanning in software development outsourcing: Implications for project performance. Information Systems Research, 21(4), 960-982. https://doi.org/10.1287/isre.1080.0205

Grau, D., Back, W. E., \& Mejia-Aguilar, G. (2017). Organizational-Behavior Influence on Cost and Schedule Predictability. Journal of Management in Engineering, 33(5), 04017027. https://doi.org/10.1061/(asce)me.19435479.0000542

Hatamleh, M. T., Hiyassat, M., Sweis, G. J., \& Sweis, R. J. (2018). Factors affecting the accuracy of cost estimate: Case of Jordan. Engineering, Construction and Architectural Management, 25(1), $113-131$. https://doi.org/10.1108/ECAM-10-2016-0232

Henderson, J. C., \& Lee, S. (1992). Managing I/S design teams. A control theories perspective. Management Science, 38(6), 757-777. https://doi.org/10.1287/mnsc.38.6.757

Howell, D., Windahl, C., \& Seidel, R. (2010). A project contingency framework based on uncertainty and its consequences. International Journal of Project Management, 28(3), $256-264$. https://doi.org/10.1016/j.ijproman.2009.06.002

Islam, M. S., Nepal, M. P., \& Skitmore, M. (2019). Modified Fuzzy Group Decision-Making Approach to Cost Overrun Risk Assessment of Power Plant Projects. Journal of Construction Engineering and Management, 145(2), 04018126. https://doi.org/10.1061/(asce)co.1943-7862.0001593 
Jonny Klakegg, O., Torp, O., \& Austeng, K. (2010). Good and simple - a dilemma in analytical processes? International Journal of Managing Projects in Business, 3(3), 402-421. https://doi.org/10.1108/17538371011056057

Jørgensen, M., Halkjelsvik, T., \& Kitchenham, B. (2012). How does project size affect cost estimation error? Statistical artifacts and methodological challenges. International Journal of Project Management, 30(7), 839-849. https://doi.org/10.1016/j.ijproman.2012.01.007

Keltner, B., \& Finegold, D. (1996). Adding Value in Banking: Human Resource Innovations for Service Firms. Sloan Management Review, 38(1), 57-68.

Kirsch, L. J. (1997). Portfolios of Control Modes and IS Project Management. Information Systems Research, 8(3), 215239. https://doi.org/10.1287/isre.8.3.215

Kirsch, L. J., Sambamurthy, V., Ko, D. G., \& Purvis, R. L. (2002). Controlling information systems development projects: The view from the client. Management Science, 48(4), 484-498. https://doi.org/10.1287/mnsc.48.4.484.204

Lee, C. K., Yiu, T. W., \& Cheung, S. O. (2016). Selection and use of Alternative Dispute Resolution (ADR) in construction projects - Past and future research. International Journal of Project Management, 34(3), $494-507$. https://doi.org/10.1016/j.ijproman.2015.12.008

Leung, M. Y., Olomolaiye, P., Chong, A., \& Lam, C. C. Y. (2005). Impacts of stress on estimation performance in Hong Kong. Construction Management and Economics, 23(9), 891-903. https://doi.org/10.1080/0144619042000326701

Lim, B., Nepal, M. P., Skitmore, M., \& Xiong, B. (2016). Drivers of the accuracy of developers' early stage cost estimates in residential construction. Journal of Financial Management of Property and Construction, 21(1), 4-20. https://doi.org/10.1108/JFMPC-01-2015-0002

Littlejohn, S., Foss, K., \& Gossett, L. M. (2012). Organizational Control Theory. Encyclopedia of Communication Theory, 1-4. https://doi.org/10.4135/9781412959384.n267

Litzky, B. E., Eddleston, K., \& Kidder, D. L. (2006). The good, the bad, and the misguided: How managers inadvertently encourage deviant behaviors. Academy of Management Perspectives, 20(1), 91-103. https://doi.org/10.5465/AMP.2006.19873411

Liu, L., \& Zhu, K. (2007). Improving Cost Estimates of Construction Projects Using Phased Cost Factors. Journal of Construction Engineering and Management, 133(1), 91-95. https://doi.org/10.1061/(asce)07339364(2007)133:1(91)

Lowe, D., \& Skitmore, M. (1994). Experiential learning in cost estimating. Construction Management and Economics, 12(5), 423-431. https://doi.org/10.1080/01446199400000052

Luo, L., He, Q., Xie, J., Yang, D., \& Wu, G. (2017). Investigating the Relationship between Project Complexity and Success in Complex Construction Projects. Journal of Management in Engineering, 33(2), 04016036. https://doi.org/10.1061/(asce)me.1943-5479.0000471

Mahamid, I. (2015). Factors affecting cost estimate accuracy: Evidence from Palestinian construction projects. International Journal of Management Science and Engineering Management, 10(2), 117-125. https://doi.org/10.1080/17509653.2014.925843

Mahdi, I., \& Soliman, E. (2021). Significant and top ranked delay factors in Arabic Gulf countries. International Journal of Construction Management, 21(2), 167-180. https://doi.org/10.1080/15623599.2018.1512029

Membah, J., \& Asa, E. (2015). Estimating cost for transportation tunnel projects: A systematic literature review. International Journal of Construction $\quad$ Management, $\quad 15(3), \quad 196-218$. https://doi.org/10.1080/15623599.2015.1067345

Morrison, N. (1984). The accuracy of quantity surveyors' cost estimating. Construction Management and Economics, 2(1), 57-75. https://doi.org/10.1080/01446198400000006

Oberlender, G. D., \& Trost, S. M. (2001). Predicting Accuracy of Early Cost Estimates Based on Estimate Quality. Journal of Construction Engineering and Management, 127(3), 173-182. https://doi.org/10.1061/(asce)07339364(2001)127:3(173)

Ogunlana, O. (1991). Learning from experience in design cost estimating. Construction Management and Economics, 9(2), 133-150. https://doi.org/10.1080/01446199100000012

Ouchi, W. G. (1979). Conceptual Framework for the Design of Organizational Control Mechanisms. Management Science, 25(9), 833-848. https://doi.org/10.1287/mnsc.25.9.833

Project Management Institute. (2018). Success in disruptive times: expanding the value delivery landscape to address the high cost of low performance. In Pulse of the Profession. https://www.pmi.org/learning/thoughtleadership/pulse/pulse-of-the-profession-2018

Reid, G. C., \& Smith, J. A. (2000). The impact of contingencies on management accounting system development. Management Accounting Research, 11(4), 427-450. https://doi.org/10.1006/mare.2000.0140

Shehu, Z., Endut, I. R., \& Akintoye, A. (2014). Factors contributing to project time and hence cost overrun in the Malaysian construction industry. Journal of Financial Management of Property and Construction, 19(1), 55-75. https://doi.org/10.1108/JFMPC-04-2013-0009

Siddaway, A. P., Wood, A. M., \& Hedges, L. V. (2019). How to Do a Systematic Review: A Best Practice Guide for Conducting and Reporting Narrative Reviews, Meta-Analyses, and Meta-Syntheses. Annual Review of Psychology, 70(1), 747-770. https://doi.org/10.1146/annurev-psych-010418-102803

Sihag, V., \& Rijsdijk, S. A. (2019). Organizational Controls and Performance Outcomes: A Meta-Analytic Assessment and Extension. Journal of Management Studies, 56(1), 91-133. https://doi.org/10.1111/joms.12342

Snell, S. A. (1992). Control Theory In Strategic Human Resource Management: The Mediating Effect Of Administrative 
Information. Academy of Management Journal, 35(2), 292-327. https://doi.org/10.5465/256375

Soutos, M., \& Lowe, D. J. (2011). Elemental cost estimating: Current UK practice and procedure. Journal of Financial Management of Property and Construction, 16(2), 147-162. https://doi.org/10.1108/13664381111153123

Spies, R., Grobbelaar, S., \& Botha, A. (2020). A Scoping Review of the Application of the Task-Technology Fit Theory. Lecture Notes in Computer Science (Including Subseries Lecture Notes in Artificial Intelligence and Lecture Notes in Bioinformatics), 12066 LNCS, 397-408. https://doi.org/10.1007/978-3-030-44999-5_33

Sridarran, P., Keraminiyage, K., \& Herszon, L. (2017). Improving the cost estimates of complex projects in the projectbased industries. Built Environment Project and Asset Management, 7(2), $173-184$. https://doi.org/10.1108/BEPAM-10-2016-0050

Tah, J. H. M., Thorpe, A., \& McCaffer, R. (1994). A survey of indirect cost estimating in practice. Construction Management and Economics, 12(1), 31-36. https://doi.org/10.1080/01446199400000004

Tayefeh Hashemi, S., Ebadati, O. M., \& Kaur, H. (2020). Cost estimation and prediction in construction projects: a systematic review on machine learning techniques. SN Applied Sciences, 2(10), 1-27. https://doi.org/10.1007/s42452-020-03497-1

Tiwana, A. (2010). Systems development ambidexterity: Explaining the complementary and substitutive roles of formal and informal controls. Journal of Management Information Systems, 27(2), 87-126. https://doi.org/10.2753/MIS0742-1222270203

Trost, S. M., \& Oberlender, G. D. (2003). Predicting Accuracy of Early Cost Estimates Using Factor Analysis and Multivariate Regression. Journal of Construction Engineering and Management, 129(2), $198-204$. https://doi.org/10.1061/(asce)0733-9364(2003)129:2(198)

Turner, K. L., \& Makhija, M. V. (2006). The role of organizational controls in managing knowledge. Academy of Management Review, 31(1), 197-217. https://doi.org/10.5465/amr.2006.19379631

Uher, T. E. (1996). Cost estimating practices in Australian construction. Engineering, Construction and Architectural Management, 3(1-2), 83-95. https://doi.org/10.1108/eb021024

Williamson, H. F., \& Chandler, A. D. (1964). Strategy and Structure: Chapters in the History of the Industrial Enterprise. In Technology and Culture (Vol. 5, Issue 1). M.I.T. Press. https://doi.org/10.2307/3101138

Wing, C. K. (1997). The ranking of construction management journals. Construction Management and Economics, 15(4), 387-398. https://doi.org/10.1080/014461997372953

Woods, M. (2009). A contingency theory perspective on the risk management control system within Birmingham City Council. Management Accounting Research, 20(1), 69-81. https://doi.org/10.1016/j.mar.2008.10.003

Yang, J., \& Cheng, Q. (2021). The Conditional Limitation of Relational Governance: The Moderating Role of Project Complexity. Advances in Civil Engineering, 2021, 1-14. https://doi.org/10.1155/2021/8886913

Yu, B., \& To, W. M. (2011). The importance of input control to work performance under the agency theory framework. International Journal of Human Resource Management, 22(14), $2874-2891$. https://doi.org/10.1080/09585192.2011.606125 


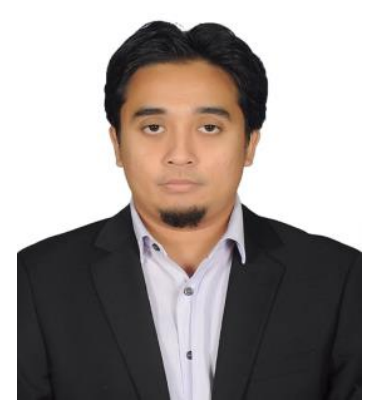

Mohammad Waffy Bin Fazil is a PhD candidate and fellow in Project Management at Faculty of Industrial Management. He has 1 year of working experience in engineering consulting industry. He received his Master in Project Management from University of Queensland in 2016 and also Bachelor of Mechanical Engineering from University of Western Australia in 2013. mohammad.waffy@gmail.com

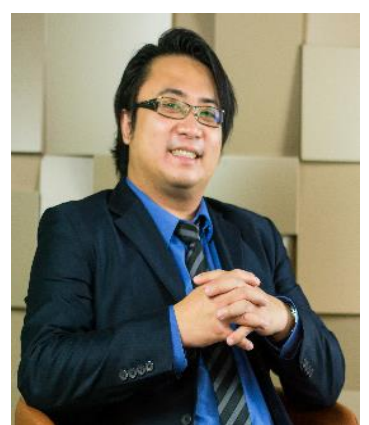

Dr. Chia Kuang LEE is a Senior Lecturer in Faculty of Industrial Management, Universiti Malaysia Pahang. Dr Lee has received his Bachelor Degree in Quantity Surveying and Master of Science in Construction Contract Management from Universiti Teknologi Malaysia (UTM). In 2017, he received a PhD in Civil Engineering from The University of Auckland which focus on Construction Alternative Dispute Resolution (A.D.R.) method. His research interests are Project Management and specialize in construction management and project management. chia@ump.edu.my

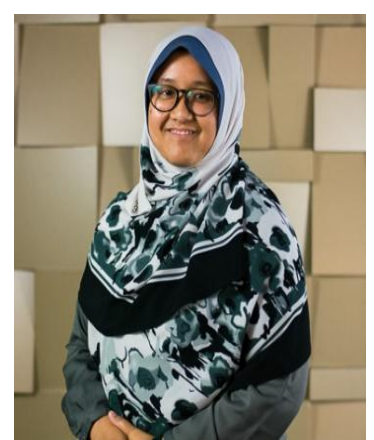

Currently the Deputy Dean of Research and Postgraduate Studies in Faculty of Industrial Management, Universiti Malaysia Pahang. She has received PhD in Business Management from Universiti Technology MARA and BSc, and MSc degrees in Bioresources, Paper and Coating Technology from Universiti Sains Malaysia. She had 4 years' experience in the furniture and wood flooring industry and responsible for Quality Control and Production processes. Her research interests are Business Management, Innovation Management, Product Management, and Research Methodology. fadzline@ump.edu.my 